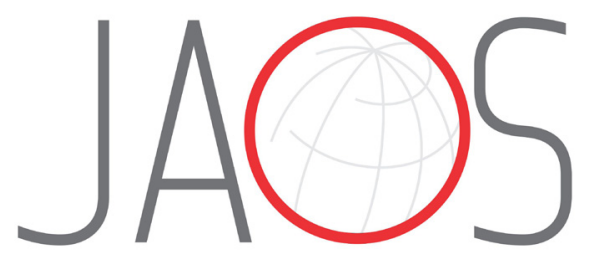
JOURNAL OF APPLIED ORAL SCIENCE

\title{
Influence of surfactants addition on the properties of calcium hypochlorite solutions
}

\section{Abstract}

Júlia Eick IGLESIAS ${ }^{1}$

Lucas Siqueira PINHEIRO

Daniel Eduardo WEIBEL ${ }^{2}$

Francisco MONTAGNER ${ }^{1}$

Fabiana Soares GRECCA ${ }^{1}$
Submitted: April 7, 2018 Modification: August 7, 2018

Accepted: August 21, 2018

Corresponding address: Fabiana Soares Grecca

Rua Ramiro Barcelos, 2492 - Bairro Santana 90035-003 - Porto Alegre - RS - Brasil. Phone: +55 5133085191 - Fax: +55 5133085010 e-mail: fabiana.grecca@ufrgs.br
Objectives: The aim of this study was to evaluate the influence of surfactants $0.2 \%$ or $0.1 \%$ cetrimide (Cet) or $0.008 \%$ benzalkonium chloride (BAK) on $2.5 \%$ calcium hypochlorite $\left(\mathrm{Ca}(\mathrm{OCl})_{2}\right)$, and compare to sodium hypochlorite $(\mathrm{NaOCl})$, regarding the properties of $\mathrm{pH}$, free chlorine content, surface tension, contact angle, pulp dissolution and antimicrobial activity. Material and Methods: The $\mathrm{pH}$ and free chlorine content were evaluated by digital pHmeter and by titration, respectively. Surface tension was measured by the platinum ring technique with a Du Noüy tensiometer. The solution's contact angle in human dentin surfaces was checked by Drop Shape Analyzer software. Bovine pulps were used for pulp dissolution analysis and the dissolving capacity was expressed by percent weight loss. Antimicrobial activity over Enterococcus faecalis was evaluated by the agar diffusion method. Results: Surfactants addition to $\mathrm{Ca}(\mathrm{OCl})_{2}$ and $\mathrm{NaOCl}$ did not alter the $\mathrm{pH}$, free chlorine content and pulp dissolution properties. $\mathrm{Ca}(\mathrm{OCl})_{2}$ had the highest surface tension among all tested solutions. When surfactants were added to $\mathrm{Ca}(\mathrm{OCl})_{2}$ and $\mathrm{NaOCl}$, there was a significant reduction of surface tension and contact angle values. The addition of $0.2 \%$ or $0.1 \%$ Cet enhanced antimicrobial activity of both $\mathrm{Ca}(\mathrm{OCl})^{2}$ and $\mathrm{NaOCl}$. Conclusion: Surfactant addition to $2.5 \% \mathrm{Ca}(\mathrm{OCl})^{2}$ has shown acceptable outcomes for $\mathrm{pH}$, free chlorine content, surface tension, contact angle, pulp dissolution and antimicrobial activity. Furthermore, the addition of $0.2 \%$ Cet showed better results for all tested properties.

Keywords: Calcium hypochlorite. Endodontics. Root canal irrigants. Sodium hypochlorite. Surface tension.

'Universidade Federal do Rio Grande do Sul, Faculdade de Odontologia, Departamento de Odontologia Conservadora, Porto Alegre, Rio Grande do Sul, Brasil.

2Universidade Federal do Rio Grande do Sul, Instituto de Química, Departamento de Físico-Química, Porto Alegre, Rio Grande do Sul, Brasil. 


\section{Introduction}

Root canals present a complex internal anatomy with irregularities and isthmus, which may not be accessible during instrumentation. Hence, irrigation is an important step of the root canal treatment and should allow the irrigant to reach those areas. ${ }^{1}$ The ideal root canal irrigant should have antimicrobial spectrum, including action against biofilms, dissolve pulp and necrotic tissue, inactivate endotoxin, prevent/remove smear layer and not injure the periapical tissue in case of accidental contact. ${ }^{1}$ Moreover, irrigants with lower surface tension may penetrate more in dental tubules, with greater antimicrobial activity. ${ }^{2}$

Sodium hypochlorite $(\mathrm{NaOCl})$ is the most used irrigant solution in clinical practice, because it has the unique capacity to dissolve necrotic tissue and organic components of the smear layer. ${ }^{1}$ However, its chemical instability can influence the availability of chlorine ions and interfere with the desired characteristics of the irrigant. ${ }^{3}$ In this regard, other auxiliary chemicals should be studied.

Calcium hypochlorite $\left(\mathrm{Ca}(\mathrm{OCl})_{2}\right)$ is a white powder that can be dissolved in distilled water, used for industrial sterilization and purifying water treatment. ${ }^{4}$ It is relatively stable and shows more available chlorine content than $\mathrm{NaOCl}^{3,5}$ Studies demonstrated the potential of $\mathrm{Ca}(\mathrm{OCl})_{2}$ solutions to dissolve tissue $\mathrm{e}^{5,6}$ and antimicrobial action against $E$. faecalis ${ }^{7}$. Also, $\mathrm{Ca}(\mathrm{OCl})_{2}$ showed favorable results of viability and induced a low-level inflammatory response when compared with $\mathrm{NaOCl}{ }^{8}$

Nevertheless, aqueous solutions of $\mathrm{NaOCl}$ and $\mathrm{Ca}(\mathrm{OCl})_{2}$ have high surface tension values. ${ }^{3,7,9}$ Surface tension is related to the wetting ability, surface free energy or capillarity effects. ${ }^{10-12}$ It allows solution penetration into both the main and lateral canals and into the dentinal tubules. ${ }^{1,12}$ On the other hand, surface free energy is the result of intermolecular interactions between the surface and the liquid. It can be expressed as the contact angle between a drop of liquid on a solid surface. ${ }^{10,11}$ The lower the surface tension and contact angle, the better the wettability potential of the solution. ${ }^{11}$

Cetrimide (Cet) is a cationic surfactant (quaternary ammonium salt) available as a white odorless powder and, according to the manufacturer, it is highly hygroscopic. It has the capacity of lowering surface tension, ${ }^{12}$ and antimicrobial activity. ${ }^{13-15}$ Benzalkonium chloride (BAK) is also a cationic surfactant, already used in dental clinical practice and associated with some endodontic irrigants. ${ }^{16}$ The antibacterial potential of BAK is associated with changes promoted on the ionic resistance of the cell membrane. ${ }^{17}$

The addition of surfactants to $\mathrm{NaOCl}$ as an alternative to decrease their high surface tension has been reported in the past. ${ }^{9,12,16,18}$ Furthermore, previous studies have shown bactericidal activity even when surfactants were used $^{19,20}$. However, there are no data concerning the effect of the addition of surfactants to $\mathrm{Ca}(\mathrm{OCl})_{2}$.

Therefore, the objective of this study was to add surfactants $\mathrm{Ca}(\mathrm{OCl})_{2}$ and evaluate the effect on the properties of $\mathrm{pH}$, chlorine content, surface tension, contact angle, pulp dissolution and antimicrobial capacity.

\section{Material and methods}

This study was approved by the Institutional Review Board (Protocols n. 29495 and 59004516.4.0000.5347).

\section{Preparation of $\mathrm{NaOCl}$ and $\mathrm{Ca}(\mathrm{OCl})_{2}$, solutions}

The solutions were titrated by the sodium thiosulfate method as described by Vogel ${ }^{21}(1965)$, and prepared immediately before the experiments. An aliquote of 10 $\mathrm{mL}$ of the tested solution was added to $90 \mathrm{~mL}$ of distilled water. $15 \mathrm{~mL}$ of the diluted solution was transferred to a $250 \mathrm{~mL}$ Erlenmeyer flask. To stain the sample, $1 \mathrm{~mL}$ of the potassium iodide solution and $1.7 \mathrm{~mL}$ of the $0.1 \mathrm{~N}$ sulfuric acid solution were added. Titration was performed with $0.1 \mathrm{~N}$ sodium thiosulfate until the solution in question became clear. Chlorine content was calculed as follows:

Calculus 1:

$0.0036 \mathrm{~g}$ chlorine $-1 \mathrm{~mL}$ sodium thiosulfate

a - thiosulfate used in titratrion $(\mathrm{mL})$

Calculus 2:

$15 \mathrm{~mL}$ - a (chlorine in $15 \mathrm{~mL}$ )

$100 \mathrm{~mL}-\mathrm{b}$ (active chlorine in the diluted solution)

Calculus 3:

b $\times 10$ (solution was diluted ten times)

A $12 \% \mathrm{NaOCl}$ solution (Farmaquímica S.A. Produtos Químicos; Porto Alegre, Rio Grande do Sul, Brazil) was diluted in sterilized and distilled water to reach the $2.5 \%$ concentration. To obtain a $2.5 \% \mathrm{Ca}(\mathrm{OCl})_{2}$ solution, $3.8461 \mathrm{~g}$ of $\mathrm{Ca}(\mathrm{OCl})_{2}$ powder, with $65 \%$ purity (Farmaquímica S.A. Produtos Químicos; Porto Alegre, 
Rio Grande do Sul, Brazil), was mixed with $100 \mathrm{~mL}$ of sterile distilled water. All solutions were prepared under constant agitation and were stored in bottles identified with random numbers for blinding.

The surfactants added to $\mathrm{Ca}(\mathrm{OCl})_{2}$ and $\mathrm{NaOCl}$ solutions were $0.2 \%$ cetrimide $(0.2 \% \text { Cet })^{13-15}, 0.1 \%$ cetrimide $(0.1 \% \text { Cet })^{19}$ or $0.008 \%$ benzalkonium chloride (BAK). ${ }^{16}$ Distilled water (DW) was used as control group, as follows:

Group I: control, distilled water

Group II: $2.5 \% \mathrm{NaOCl}$

Group III: $2.5 \% \mathrm{NaOCl}+0.2 \%$ cetrimide

Group IV: $2.5 \% \mathrm{NaOCl}+0.1 \%$ cetrimide

Group V: $2.5 \% \mathrm{NaOCl}+0.008 \%$ BAK

Group VI: $2.5 \% \mathrm{Ca}(\mathrm{OCl})_{2}$

Group VII: $2.5 \% \mathrm{Ca}(\mathrm{OCl})_{2}+0.2 \%$ cetrimide

Group VIII: $2.5 \% \mathrm{Ca}(\mathrm{OCl})_{2}+0.1 \%$ cetrimide

Group IX: $2.5 \% \mathrm{Ca}(\mathrm{OCl})_{2}+0.008 \%$ BAK

Group X: $0.2 \%$ cetrimide

Group XI: $0.1 \%$ cetrimide

Group XII: $0.008 \%$ BAK

\section{$\mathrm{pH}$ measurement}

The $\mathrm{pH}$ ( $\mathrm{n}=3$ for each solution) was obtained immediately after manipulation and triplicate. Each sample was measured by a digital pHmeter (Digimed; São Paulo, São Paulo, Brazil). Calibration was performed according to the manufacturer's instructions, and a buffer at a pH of 10 was used as a control for each analysis.

\section{Determination of the available chlorine content}

The available chlorine content $(n=3$ for each solution) was evaluated by sodium thiosulfate titration ${ }^{21}$ as described previously, and triplicate. The result was expressed in grams of active chlorine per $100 \mathrm{~mL}$ solution.

\section{Surface tension measurement}

Surface tension was evaluated by the "ring method". ${ }^{22}$ The Du Noüy tensiometer (Sigma; Attension, Espoo, Finland) was used in a room at constant temperature $\left(25^{\circ} \mathrm{C}\right)$.

The equipment measures the strength needed to separate the platinum ring from within a solution after it has been submerged. Distilled water was used as the control and to perform initial calibration of the instrument. Twenty $\mathrm{mL}$ of the tested solution was positioned so that the ring could submerge. As the equipment slowly removed the ring from the liquid, it recorded solutions surface tension value. The test was performed in 3 samples of each solution and triplicate. Results were expressed in $\mathrm{mN} / \mathrm{m}$.

\section{Contact angle measurement}

Thirty single-rooted extracted human teeth were obtained. The crown was removed at the cementoenamel junction, and the roots were longitudinally sectioned in two halves, mesial and distal. Each half was transversely divided in 2 pieces, cervical and apical. Four dentin specimens were obtained from each tooth. A total of 120 specimens (10 per group) were obtained, and stratified so that each group received 5 cervical and 5 apical specimens.

The specimens were embedded in self-curing acrylic resin (Jet Clássico; Campo Limpo Paulista, São Paulo, Brazil) with the root canal surface facing up. The surfaces were polished under running water using 80-, 100-, 120-, 150- and 180-grit abrasive papers to obtain a flat wide dentin surface. ${ }^{10,16,20}$

Contact angle measurements were achieved at $22^{\circ} \mathrm{C}$ by using a drop shape analysis system DSA100 (Kruss; Hamburg, Hamburg, Germany). A drop with 2 $\mu \mathrm{l}$ volume of tested solution was carefully placed with a micropipette on each dentin surface. After 30 seconds, the image of the droplet was obtained and the contact angle was calculated. ${ }^{10,16,20}$

Three parallel measurements were performed with each tested solution on both cervical and apical thirds.

Dentin specimens were polished to create a smooth and flat dentin surface, ${ }^{16}$ otherwise the program would not be able to measure contact angle inside the concave surface of root canal walls. The samples did not receive any superficial treatment, in order to simulate the presence of smear layer during root canal preparation and to observe solutions ability to penetrate in dentine tubules.

\section{Pulp dissolution test}

Bovine pulp tissue was employed for the experiment. Teeth were extracted and stored at $-20^{\circ} \mathrm{C}$ until required. The crowns were removed at the cementoenamel junction and the pulp tissue was removed. One-hundred twenty standardized pulp fragments (10 per group) with length of $5 \mathrm{~mm}$ and weight ranging from 0.015 and $0.025 \mathrm{~g}$ were prepared using a scalpel blade number 15 (MedGolman; São José, Santa Catarina, Brazil). The initial weight of each specimen was measured with a precision scale M1203 (BEL Engeneering; Monza, Monza and Brianza, Itália) in an airtight container. After weight 
recording, the specimens were randomly divided.

The pulp fragment was placed in a cell culture well and each specimen was irrigated with a total volume of $10 \mathrm{~mL}$ of solution, for 10 minutes. One $\mathrm{mL}$ of the solution was replaced every minute. At the end of the irrigation time, the specimens were removed from the wells and left in contact with a sterile absorbent paper for 30 seconds to remove the excess solution. The specimens were weighed to assess their final weight. The percentage of weight loss was determined for each sample. ${ }^{23-25}$ All specimens were weighed by a single investigator, which was unaware of how each was to be treated.

\section{Antimicrobial test}

The agar diffusion method was used to measure the antimicrobial activity. The test was performed in 3 samples of each solution and triplicate. The strain used in the analysis was Enterococcus faecalis (ATCC 29212). The subcultures were incubated at $37^{\circ} \mathrm{C}$ for 48 hours prior to testing of the solutions and their base components. The purity of strains was checked by subculture of the inocula onto Brain Heart Infusion Agar (Himedia Laboratories Limited; Ghatkopar West, Mumbai, India) supplemented with 5\% defibrinated sheep blood for $E$. faecalis. Agar well diffusion assays were performed in 90-mm diameter Petri dishes containing Mueller Hinton Agar (Himedia Laboratories Limited; Ghatkopar West, Mumbai, India) for E. faecalis at a depth of $4 \mathrm{~mm}$. A direct colony suspension isolate was prepared in $0.85 \%$ sterile saline, and the turbidity was adjusted to a 0.5 McFarland standard. The agar plates were flooded with the test suspension and sterilized filter paper disks containing $20 \mu \mathrm{L}$ of test solution were placed over the agar. The plates were then incubated at $37^{\circ} \mathrm{C}$ for 24 hours. After incubation, the diameters of the growth inhibition zones were measured in millimeters to the nearest $0.1 \mathrm{~mm}$ using electronic calipers (Digimess Instrumentos de Precisão Ltda; São Paulo, São Paulo, Brazil).

\section{Statistical analysis}

The data were submitted to a normality test (Kolmogorov-Smirnov) and homocedasticity test (Levene). For free chlorine, surface tension, pulp dissolution and antimicrobial activity tests, since data were normal and had homocedasticity, One-way ANOVA was used, followed by Tukey post hoc. For contact angle tests, Kruskal-Wallis followed by paired comparison was used. Data analysis was performed by SPSS (Statistical
Package for Social Science) for Mac version 20 at a 5\% significance level.

\section{Results}

\section{$\mathrm{pH}$ measurement}

All $\mathrm{NaOCl}$ and $\mathrm{Ca}(\mathrm{OCl})_{2}$, with or without the addition of surfactants had a pH level above 11 . Surfactants alone and DW had pH values around 7 (Table 1).

\section{Determination of the available chlorine content}

DW, $0.2 \%$ and $0.1 \%$ Cet, and BAK did not present chlorine content and were not included in the statistical analysis. $\mathrm{NaOCl}+0.1 \%$ Cet and $\mathrm{NaOCl}+\mathrm{BAK}$ had the higher amount of chlorine content, with a statistical difference to $\mathrm{Ca}(\mathrm{OCl})_{2}$ solutions, with or without surfactant addition $(p<0.05)$ (Table 2$)$.

Table 1- $\mathrm{pH}$ readings of tested solutions (median, maximum and minimum values)

\begin{tabular}{lc}
\hline \multicolumn{1}{c}{ Group } & pH values (max/min) \\
\hline $\mathrm{DW}$ & $7.76(7.66-8.18)$ \\
$\mathrm{NaOCl}$ & $12.88(12.86-12.94)$ \\
$\mathrm{NaOCl}+0.2 \%$ Cet & $12.72(12.68-12.76)$ \\
$\mathrm{NaOCl}+0.1 \%$ Cet & $12.76(12.74-12.77)$ \\
$\mathrm{NaOCl}+\mathrm{BAK}$ & $11.80(11.78-11.89)$ \\
$\mathrm{Ca}(\mathrm{OCl})^{2}$ & $12.65(12.59-12.66)$ \\
$\mathrm{Ca}(\mathrm{OCl})_{2}+0.2 \%$ Cet & $11.89(11.88-11.96)$ \\
$\mathrm{Ca}(\mathrm{OCl})_{2}+0.1 \%$ Cet & $11.87(11.84-11.87)$ \\
$\mathrm{Ca}(\mathrm{OCl})_{2}+\mathrm{BAK}$ & $11.77(11.56-11.80)$ \\
$0.2 \% \mathrm{Cet}$ & $7.10(6.82-7.35)$ \\
$0.1 \% \mathrm{Cet}$ & $6.35(6.29-6.50)$ \\
$\mathrm{BAK}$ & $7.03(6.75-7.15)$ \\
\hline
\end{tabular}

Table 2- Avaliable chlorine content (mean \pm SD)

\begin{tabular}{lc}
\hline \multicolumn{1}{c}{ Group } & Chlorine content \\
\hline $\mathrm{NaOCl}$ & $2.93 \pm 0.13^{\mathrm{abc}}$ \\
$\mathrm{NaOCl}+0.2 \%$ Cet & $3.01 \pm 0.16^{\mathrm{ab}}$ \\
$\mathrm{NaOCl}+0.1 \% \mathrm{Cet}$ & $3.16 \pm 0.19^{\mathrm{a}}$ \\
$\mathrm{NaOCl}+\mathrm{BAK}$ & $3.24 \pm 0.07^{\mathrm{a}}$ \\
$\mathrm{Ca}(\mathrm{OCl})_{2}$ & $2.73 \pm 0.08^{\mathrm{bc}}$ \\
$\mathrm{Ca}(\mathrm{OCl})_{2}+0.2 \% \mathrm{Cet}$ & $2.77 \pm 0.08^{\mathrm{bc}}$ \\
$\mathrm{Ca}(\mathrm{OCl})_{2}+0.1 \% \mathrm{Cet}$ & $2.58 \pm 0.09^{\mathrm{c}}$ \\
$\mathrm{Ca}(\mathrm{OCl})_{2}+\mathrm{BAK}$ & $2.63 \pm 0.08^{\mathrm{c}}$ \\
\hline
\end{tabular}

Different letters indicate statistical difference between solutions ANOVA (Tukey post hoc) $(\mathrm{p}<0.05)$ 


\section{Surface tension measurement}

$\mathrm{Ca}(\mathrm{OCl})_{2}$ had the highest surface tension among all tested solutions. Surfactant addition to $\mathrm{NaOCl}$ and $\mathrm{Ca}(\mathrm{OCl})_{2}$ lowered the surface tension values, independently of the surfactant added, with statistical difference $(p<0.05)$ (Table 3 ).

\section{Contact angle measurement}

Representative images of the analyzed groups (DW, $\mathrm{NaOCl}, \mathrm{Ca}(\mathrm{OCl})_{2}$ and $\left.\mathrm{BAK}\right)$ can be found in Figure 1 .

Contact angle values $<10^{\circ}$ are not measured by the system. $\mathrm{NaOCl}$ and $\mathrm{Ca}(\mathrm{OCl})_{2}$ with the addition of surfactants, and $0.2 \%$ and $0.1 \%$ Cet alone had a contact angle $<10^{\circ}$, for both cervical and apical specimens, and were not included in statistical analysis.

There was no statistical difference among cervical and apical specimens when the same solution was evaluated $(p>0.05)$. Statistical difference was observed between $\mathrm{Ca}(\mathrm{OCl})_{2}$ and $\mathrm{BAK}$, in both cervical $(p=0.042)$ and apical $(p=0.041)$ thirds. $\mathrm{Ca}(\mathrm{OCl})_{2}$ presented higher contact angle than BAK (Table 4).

Table 3- Surface tension measurement in $\mathrm{mN} / \mathrm{m}$. (mean $\pm \mathrm{SD}$ )

\begin{tabular}{lc}
\hline \multicolumn{1}{c}{ Group } & Surface tension \\
\hline $\mathrm{DW}$ & $52.07 \pm 1.13^{\mathrm{b}}$ \\
$\mathrm{NaOCl}$ & $46.30 \pm 3.94^{\mathrm{c}}$ \\
$\mathrm{NaOCl}+0.2 \% \mathrm{Cet}$ & $33.08 \pm 0.07^{\text {ef }}$ \\
$\mathrm{NaOCl}+0.1 \% \mathrm{Cet}$ & $32.85 \pm 0.22^{\text {ef }}$ \\
$\mathrm{NaOCl}+\mathrm{BAK}$ & $30.92 \pm 0.24^{\mathrm{f}}$ \\
$\mathrm{Ca}(\mathrm{OCl})_{2}$ & $72.13 \pm 1.82^{\mathrm{a}}$ \\
$\mathrm{Ca}(\mathrm{OCl})_{2}+0.2 \% \mathrm{Cet}$ & $32.89 \pm 0.93^{\mathrm{ef}}$ \\
$\mathrm{Ca}(\mathrm{OCl})_{2}+0.1 \% \mathrm{Cet}$ & $33.67 \pm 0.85^{\mathrm{ef}}$ \\
$\mathrm{Ca}(\mathrm{OCl})_{2}+\mathrm{BAK}$ & $31.86 \pm 0.18^{\mathrm{f}}$ \\
$0.2 \% \mathrm{Cet}$ & $36.99 \pm 0.28^{\mathrm{de}}$ \\
$0.1 \% \mathrm{Cet}$ & $40.85 \pm 0.73^{\mathrm{d}}$ \\
$\mathrm{BAK}$ & $50.53 \pm 2.20^{\mathrm{bc}}$ \\
\hline
\end{tabular}

Different letters indicate statistical difference between solutions ANOVA (Tukey post hoc) $(\mathrm{p}<0.05)$

\section{Pulp dissolution test}

$\mathrm{NaOCl}$ solutions, with and without surfactant addition, dissolved more pulpal tissue than all other tested solutions. $\mathrm{Ca}(\mathrm{OCl})_{2}$ solutions presented pulpal dissolution ability. Surfactants alone did not have dissolution ability, as well as DW (Table 5).

\section{Antimicrobial test}

Ampicillin (positive control) had the highest antimicrobial inhibition zone. All solutions, except DW,

Table 4- Contact angle measurement in cervical and apical thirds (median, maximum and minimum values)

\begin{tabular}{lcc}
\hline \multicolumn{1}{c}{ Group } & Cervical third & Apical third \\
\hline $\mathrm{DW}$ & $48.10(38.14-55.31)^{\mathrm{ab}}$ & $50.58(49.95-61.07)^{\mathrm{AB}}$ \\
$\mathrm{NaOCl}$ & $44.27(29.16-51.97)^{\mathrm{ab}}$ & $44.63(40.51-50.57)^{\mathrm{AB}}$ \\
$\mathrm{Ca}(\mathrm{OCl})_{2}$ & $53.17(43.54-61.82)^{\mathrm{ab}}$ & $52.85(48.46-64.65)^{\mathrm{A}}$ \\
$\mathrm{BAK}$ & $42.58(28.01-45.32)^{\mathrm{b}}$ & $42.84(29.29-47.00)^{\mathrm{B}}$ \\
\hline
\end{tabular}

Different letters indicate statistical difference between solutions in the same third. Kruskal-Wallis ( paired comparison) $(p<0.05)$

Table 5- Pulp dissolution test (mean percentage reduction in weight of specimens) (mean \pm SD)

\begin{tabular}{lc}
\hline \multicolumn{1}{c}{ Group } & Pulp dissolution \\
\hline $\mathrm{DW}$ & $-40.67 \pm 25.24^{\mathrm{d}}$ \\
$\mathrm{NaOCl}$ & $88.13 \pm 11.39^{\mathrm{a}}$ \\
\hline $\mathrm{NaOCl}+0.2 \% \mathrm{Cet}$ & $83.62 \pm 9.83^{\mathrm{a}}$ \\
$\mathrm{NaOCl}+0.1 \% \mathrm{Cet}$ & $84.39 \pm 4.73^{\mathrm{a}}$ \\
$\mathrm{NaOCl}+\mathrm{BAK}$ & $86.47 \pm 6.40^{\mathrm{a}}$ \\
$\mathrm{Ca}(\mathrm{OCl})_{2}$ & $39.53 \pm 7.23^{\mathrm{b}}$ \\
$\mathrm{Ca}(\mathrm{OCl})_{2}+0.2 \% \mathrm{Cet}$ & $40.03 \pm 7.23^{\mathrm{b}}$ \\
$\mathrm{Ca}(\mathrm{OCl})_{2}+0.1 \% \mathrm{Cet}$ & $40.41 \pm 15.54^{\mathrm{b}}$ \\
$\mathrm{Ca}(\mathrm{OCl})_{2}+\mathrm{BAK}$ & $38.52 \pm 9.72^{\mathrm{b}}$ \\
$0.2 \% \mathrm{Cet}$ & $-4.42 \pm 5.02^{\mathrm{c}}$ \\
\hline $0.1 \% \mathrm{Cet}$ & $-12.97 \pm 12.27^{\mathrm{c}}$ \\
$\mathrm{BAK}$ & $-50.65 \pm 20.42^{\mathrm{d}}$ \\
\hline
\end{tabular}

Different letters indicate statistical difference between solutions ANOVA (Tukey post hoc) $(p<0.05)$
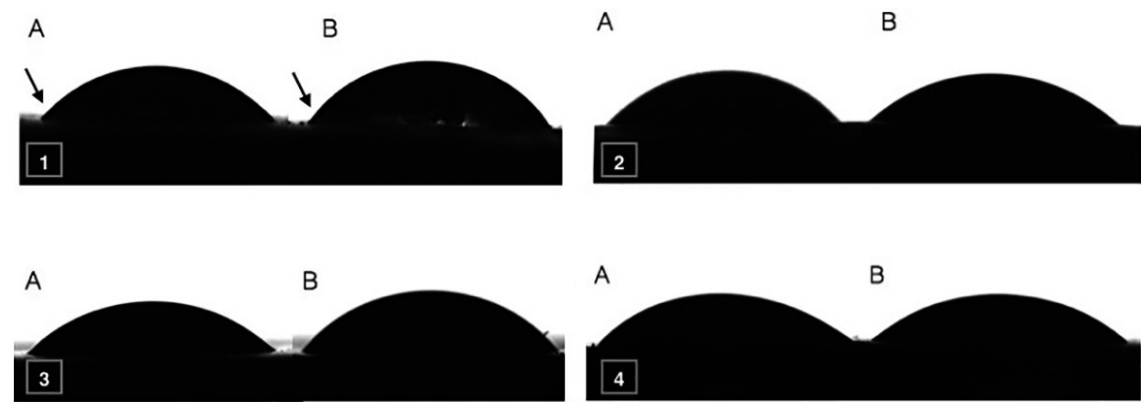

Figure 1- Representative images of solutions contact angle analysis on dentin surfaces (1) DW; (2) NaOCl; (3) $\mathrm{Ca}(\mathrm{OCl})_{2}$; (4) BAK. (A) cervical third; (B) apical third 
Table 6- Inhibition zone against Enterococcus faecalis (mm) (mean $\pm \mathrm{SD}$ ). Ampicilline was the positive control

\begin{tabular}{lc}
\hline \multicolumn{1}{c}{ Group } & Inhibition zone \\
\hline $\mathrm{DW}$ & $0.00^{\mathrm{g}}$ \\
$\mathrm{NaOCl}$ & $13.76 \pm 2.06^{\text {ef }}$ \\
$\mathrm{NaOCl}+0.2 \% \mathrm{Cet}$ & $21.21 \pm 1.35^{\mathrm{b}}$ \\
$\mathrm{NaOCl}+0.1 \% \mathrm{Cet}$ & $19.77 \pm 4.55^{\mathrm{bc}}$ \\
$\mathrm{NaOCl}+\mathrm{BAK}$ & $16.69 \pm 2.07^{\text {cde }}$ \\
$\mathrm{Ca}(\mathrm{OCl})_{2}$ & $14.23 \pm 1.65^{\text {ef }}$ \\
$\mathrm{Ca}(\mathrm{OCl})_{2}+0.2 \%$ Cet & $20.84 \pm 1.01^{\mathrm{b}}$ \\
$\mathrm{Ca}(\mathrm{OCl})_{2}+0.1 \% \mathrm{Cet}$ & $18.40 \pm 2.12^{\mathrm{bcd}}$ \\
$\mathrm{Ca}(\mathrm{OCl})_{2}+\mathrm{BAK}$ & $16.72 \pm 2.79^{\text {cde }}$ \\
\hline $0.2 \% \mathrm{Cet}$ & $18.50 \pm 1.08^{\text {bcd }}$ \\
\hline $0.1 \% \mathrm{Cet}$ & $16.52 \pm 0.98 \mathrm{~d}^{\mathrm{e}}$ \\
$\mathrm{BAK}$ & $12.18 \pm 2.07^{\mathrm{f}}$ \\
\hline Ampiciline & $31.60 \pm 0.86^{\mathrm{a}}$ \\
\hline
\end{tabular}

Different letters indicate statistical difference between solutions ANOVA (Tukey post hoc) $(\mathrm{p}<0.05)$

had antimicrobial activity against $E$. faecalis. Addition of 0.2 or $0.1 \%$ Cet to $\mathrm{NaOCl}$ and $\mathrm{Ca}(\mathrm{OCl})_{2}$ enhanced their inhibition zone $(p<0.05)$ (Table 6).

\section{Discussion}

Root canal irrigation plays a fundamental role in clinical endodontic success. The main irrigant should be able to spread along all root canal structures, enabling the clinician to promote better cleaning and shaping. The addition of surfactants to the $\mathrm{Ca}(\mathrm{OCl})_{2}$ solution reduced its surface tension, possibly enhancing its wetting ability, which may enable a better diffusion of the irrigant on dentin walls, ${ }^{16}$ leading to improved action of the solution during endodontic treatment.

A digital pHmeter was used to determine the $\mathrm{pH}$ of solutions, as already described by other studies. ${ }^{3,12,15,26-28} \mathrm{Ca}(\mathrm{OCl})_{2}$ and $\mathrm{NaOCl}$ are strongly alkaline solutions. ${ }^{3,15,18,26}$ Even though the surfactants showed a lower $\mathrm{pH}$ than $\mathrm{Ca}(\mathrm{OCl})_{2}$ and $\mathrm{NaOCl}$, their addition to the solutions did not alter their $\mathrm{pH}$, agreeing with other study. ${ }^{18}$ This could be related to the lower concentration of surfactants compared to $\mathrm{Ca}(\mathrm{OCl})_{2}$ and $\mathrm{NaOCl}$ (two and three orders of magnitude lower for cetrimide and BAK, respectively).

Since surfactants did not alter the $\mathrm{pH}$ of solutions, they may not affect the properties directly related to it, as antimicrobial activity and pulp dissolution. Additionally, the non-polar long tail group of the surfactants and the low concentration used in the present work allow dissolution into a low surface free energy interface, such as the pulp. At lower $\mathrm{pH}$, available chlorine is in the form of hypochlorous acid, ${ }^{1}$ which has greater antimicrobial activity and is more cytotoxic. ${ }^{26}$ Moreover, solution becomes more unstable, losing a significant amount of free chlorine content and, consequently, its action potential. ${ }^{29}$ On the other hand, at higher $\mathrm{pH}$ values, available chlorine is in the form of hypochlorite ions, ${ }^{1}$ which has less antimicrobial activity but is also less cytotoxic. ${ }^{29}$

The hypochlorite concentration can be affected by many factors, such as temperature and storage conditions, ${ }^{3,15}$ and for this reason it is important to know quantitatively the free chlorine content before use. In the present work the standard thiosulphate titration method was used to obtain accuracy in actual hypochlorite concentration. ${ }^{3,29}$

The titration results showed that surfactant addition did not alter $\mathrm{Ca}(\mathrm{OCl})_{2}$ and $\mathrm{NaOCl}$ free chlorine content, as already described for $\mathrm{NaOCl}$ solutions. ${ }^{16,18,27}$ This could be explained by the low concentration of surfactants used in this study, which would not be able to affect chlorine concentration of $\mathrm{Ca}(\mathrm{OCl})_{2}$ and $\mathrm{NaOCl}$. In addition, the titration results showed that all hypochlorite solutions prepared had a higher amount of chlorine than $2.5 \%$, demonstrating the importance of the thiosulphate titration method to know the actual hypochlorite concentration. Also, analysis of the free chlorine content of solutions allows knowing their ability to act against microorganisms and organic tissue.

Facultative bacteria, such as Enterococus faecalis have been considered one of the most critical endodontic pathogens in endodontic infections, and its presence can lead to root canal treatment failure. ${ }^{30}$ Although $\mathrm{Ca}(\mathrm{OCl})_{2}$ has more hypochlorous acid release, ${ }^{5}$ there was no difference in antimicrobial activity when compared to $\mathrm{NaOCl}$, agreeing with other authors. ${ }^{7}$ The theoretical concentrations of free $\mathrm{OCl}^{-}$ used in the present study for $\mathrm{Ca}(\mathrm{OCl})_{2}$ and $\mathrm{NaOCl}$ were $0.17 \mathrm{~mol} / \mathrm{L}$ and $0.33 \mathrm{~mol} / \mathrm{L}$ respectively, which indicate that both hypochlorite solutions release approximately equal amounts of free chlorine and therefore produced similar antimicrobial activities. The surfactants used in this study have antimicrobial activity, agreeing with the results from previous studies. ${ }^{13-15}$ Their molecules are positively charged and bind strongly to bacterial cell walls and membranes because of their opposite 
negative charge, leading to progressive leakage of cytoplasmatic materials, causing cell disruption. ${ }^{31}$

The antimicrobial activity was improved compared with pure hypochlorite solutions when Cet was added at concentrations of $0.2 \%$ and $0.1 \%$. The addition of BAK did not enhance the inhibition zone of $\mathrm{NaOCl}$ and $\mathrm{Ca}(\mathrm{OCl})_{2}$ solutions, agreeing with Bukiet, et al. ${ }^{16}$ (2012). This can be explained by the lower concentration of BAK when compared to Cet. The BAK concentration was approximately 17 and 8 times lower than the Cet concentrations $(0.2 \%$ and $0.1 \%$, respectively). However, the $0.008 \%$ BAK concentration was previously tested with $\mathrm{NaOCl}$ solution, and besides lowering surface tension values, it did not affect its free chlorine content, cytotoxicity, and antimicrobial properties. ${ }^{16}$ The antimicrobial activity of $\mathrm{Ca}(\mathrm{OCl})_{2}$ and $\mathrm{NaOCl}$ solutions was similar, with no statistical difference between them.

The agar diffusion method has some limitations, such as substance ability to spread through agar, number of microorganisms inoculated, substrate $\mathrm{pH}$ value, agar viscosity, storage conditions, incubation period and microorganisms metabolic activity. ${ }^{29}$ Moreover, it is important to consider that the solution was in direct contact with the microorganisms, and clinically this does not occur throughout the entire root canal system, due to anatomical structures. ${ }^{29}$ However, this is one of the most common tests used for evaluating antibacterial activity against a chemical agent, and, also, it can be considered a relevant protocol. ${ }^{32}$

Dissolution has been studied in bovine pulp tissue ${ }^{2}$ human pulp tissue, ${ }^{33}$ bovine muscle tissue. ${ }^{5,20}$ Concerning the irrigant, few studies evaluated the tissue dissolution ability of $\mathrm{Ca}(\mathrm{OCl})_{2}{ }^{5,6}$ None of the tested surfactants had pulp dissolving ability, which can be explained by their absence of free chlorine content. Therefore, surfactant addition did not alter the dissolution ability, agreeing with other authors, who tested $\mathrm{NaOCl}$ at different concentrations. 24,27,33 However, other authors found that surfactant addition resulted in better $\mathrm{NaOCl}$ dissolution ability. ${ }^{20,27}$

The results showed that $\mathrm{Ca}(\mathrm{OCl})_{2}$ presented lower dissolution ability than $\mathrm{NaOCl}$. One of the concerns related to $\mathrm{NaOCl}$ dissolution ability is the harm to periapical tissues in case of accidental outflow. ${ }^{1}$ It has been suggested that $\mathrm{Ca}(\mathrm{OCl})_{2}$ could be less aggressive to periapical tissues. ${ }^{5}$ In this regard, $\mathrm{Ca}(\mathrm{OCl})_{2}$ could have favorable results of viability and induced low-level inflammatory response, mainly in infected immature teeth treatment.

The present study observed that specimens immersed in $\mathrm{Ca}(\mathrm{OCl})_{2}$ developed a white surface coating on the entire pulp fragment, as already described. ${ }^{3-5}$ According to Dutta, et al. ${ }^{5}$ (2012), this coating can be calcium hydroxide that may have bonded to the tissue as part of amino acid reactions of saponification and neutralization.

Leonardo, et al. $^{3}$ (2016) observed the formation of a white precipitate in the bottom of plastic tubes used for $\mathrm{Ca}(\mathrm{OCl})_{2}$, solution storage. Its composition was measured with energy-dispersive X-ray spectroscopy, which enabled detection of the individual elements of particles that were formed predominantly by calcium. The average $\mathrm{pH}$ measured for the $\mathrm{Ca}(\mathrm{OCl})_{2}$ solutions was about 12.6, which means a $\mathrm{OH}_{(\text {aq) }}^{-}$equilibrium concentration of about $0.04 \mathrm{~mol} / \mathrm{L}$. Taking into account that the solubility product constant at $25^{\circ} \mathrm{C}$ for $\mathrm{Ca}(\mathrm{OH})_{2}$ is $5.5 \times 10^{-6},{ }^{34}$ a simple calculation of the $\mathrm{OH}_{(\mathrm{aq})}^{-}$ equilibrium concentration reveals a value of 0.022 $\mathrm{mol} / \mathrm{L}$. Because the actual $\mathrm{OH}^{-}$(aq) is higher than the equilibrium concentration, $\mathrm{Ca}(\mathrm{OH})_{2}$ will precipitate at $25^{\circ} \mathrm{C}$. The formation of calcium hydroxide covering the pulp tissue could affect the action of chlorine, lowering its dissolution effect.

Surface tension measurement by the Du Noüy tensiometer was already described by other authors ${ }^{3,22}$. The value is calculated by the equipment and was expressed in $\mathrm{mN} / \mathrm{m}$, but it can also be expressed in other measurement unit such as dyne/cm or $\mathrm{mJ} / \mathrm{m}^{2}$. Since the ring method does not consider the dentin surface ${ }^{16}$ it is important to analyze not only the surface tension but also the contact angle. Surface tension reduction and lower contact angle values can improve the contact between irrigant and the dentin walls. ${ }^{9,12}$

If the contact angle value is lower than $90^{\circ}$, the substrate is wetted by the liquid; if the contact angle is greater than $90^{\circ}$, the liquid is considered nonwetting. A contact angle value equal to zero represents complete wetting. ${ }^{11}$ Thus, the lower the contact angle, the faster the liquid will spread through the dental surface. ${ }^{10}$

The addition of surfactants in both $\mathrm{Ca}(\mathrm{OCl})_{2}$ and $\mathrm{NaOCl}$ resulted in complete wetting of the dentin specimens. Among surfactants, only BAK solution had a contact angle measured by the software, yet this did not occur when it was added to hypochlorite. However, in the clinical reality, factors such as surface 
irregularities and natural moisture of the dentin, will influence this behavior.

This is the first study to evaluate surfactant addition to $\mathrm{Ca}(\mathrm{OCl})_{2}$ solutions. The prepared $\mathrm{Ca}(\mathrm{OCl})_{2}$ solutions had the higher surface tension measured among all solutions herein tested $(72.13 \pm 1.82 \mathrm{mN} / \mathrm{m})$, agreeing with Leonardo, et al. ${ }^{3}$ (2016). When surfactants were added to the $\mathrm{Ca}(\mathrm{OCl})_{2}$, solutions, there was a decrease in the surface tension of all prepared solutions, reaching similar values to the $\mathrm{NaOCl}$ solutions. The lowering of surface tensions when the surfactants were added to the hypochlorite solutions explains the decrease in the contact angle measured, reaching complete wetting of the dentin specimens.

Even with the limitations of the in vitro tests, this study observed that surfactant addition to $\mathrm{Ca}(\mathrm{OCl})_{2}$ has shown acceptable outcomes for $\mathrm{pH}$, free chlorine content, surface tension, contact angle, pulp dissolution and antimicrobial activity and physicochemical properties, which may qualify it as an irrigant in endodontic practice. When compared to $\mathrm{NaOCl}$, the standard irrigant solution, $\mathrm{Ca}(\mathrm{OCl})_{2}$ appears to be less cytotoxic ${ }^{8}$ and more stable. ${ }^{3}$ Also, the addition of $0.2 \%$ Cet showed better results regarding the antimicrobial activity, contact angle and surface tension values. The possibility of mixing the $\mathrm{Ca}(\mathrm{OCl})_{2}$ solution right before its use could provide more certainty to the dentist of having a more reliable, stable solution for clinical use. Further studies should be performed to evaluate $\mathrm{Ca}(\mathrm{OCl})_{2}$ with addition of surfactants as root canal irrigant in the clinical practice.

\section{Conclusion}

Surfactant addition to $\mathrm{Ca}(\mathrm{OCl})_{2}$ has shown acceptable outcomes for $\mathrm{pH}$, free chlorine content, surface tension, contact angle, pulp dissolution and antimicrobial activity, physicochemical properties that can qualify it as an irrigant in Endodontics. Furthermore, the addition of $0.2 \%$ Cet showed better results for all tested properties.

\section{Acknowledgements}

Supported by grants from Coordination for the Improvment of Higher Edication Personel - CAPES.

\section{References}

1- Haapasalo M, Shen Y, Wang Z, Gao Y. Irrigation in endodontics. Br Dent J. 2014;216(6):299-303.

2- Rossi-Fedele G, Prichard JW, Steier L, Figueiredo JA. The effect of surface tension reduction on the clinical performance of sodium hypochlorite in endodontics. Int Endod J. 2013;46(6):492-8.

3- Leonardo NG, Carlotto IB, Luisi SB, Kopper PM, Grecca FS, Montagner F. Calcium hypochlorite solutions: evaluation of surface tension and effect of different storage conditions and time periods over $\mathrm{pH}$ and available chlorine content. J Endod. 2016;42(4):641-5.

4- Tully EJ. A study of calcium hypochlorite as a disinfectant of water. Am J Public Health (N Y). 1914;4(5):423-35.

5- Dutta A, Saunders WP. Comparative evaluation of calcium hypochlorite and sodium hypochlorite on soft-tissue dissolution. J Endod. 2012;38(10):1395-8.

6- Taneja S, Mishra N, Malik S. Comparative evaluation of human pulp tissue dissolution by different concentrations of chlorine dioxide, calcium hypochlorite and sodium hypochlorite: an in vitro study. J Conserv Dent. 2014;17(6):541-5.

7- Almeida AP, Souza MA, Miyagaki DC, Dal Bello Y, Cecchin D, Farina AP. Comparative evaluation of calcium hypochlorite and sodium hypochlorite associated with passive ultrasonic irrigation on antimicrobial activity of a root canal system infected with Enterococcus faecalis: an in vitro study. J Endod. 2014;40(12):1953-7.

8- Blattes GB, Mestieri LB, Böttcher DE, Fossati AC, Montagner F, Grecca FS. Cell migration, viability and tissue reaction of calcium hypochlorite based-solutions irrigants: an in vitro and in vivo study. Arch Oral Biol. 2017;73(1):34-9.

9- Giardino L, Ambu E, Becce C, Rimondini L, Morra M. Surface tension comparison of four common root canal irrigants and two new irrigants containing antibiotic. J Endod. 2006;32(11):1091-3.

10- Ballal NV, Tweeny A, Khechen K, Prabhu KN, Satyanarayan, Tay FR. Wettability of root canal sealers on intraradicular dentine treated with different irrigating solutions. J Dent. 2013;41(6):556-60.

11- Koch K, Barthlott W. Superhydrophobic and superhydrophilic plant surfaces: an inspiration for biomimetic materials. Philos Trans A Math Phys Eng Sci. 2009;367(1893):1487-509.

12- Palazzi F, Morra M, Mohammadi Z, Grandini S, Giardino L. Comparison of the surface tension of $5.25 \%$ sodium hypochlorite solution with three new sodium hypochlorite-based endodontic irrigants. Int Endod J. 2012;45(2):129-35.

13- Guerreiro-Tanomaru JM, Nascimento CA, Faria-Júnior NB, Graeff MS, Watanabe E, Tanomaru-Filho M. Antibiofilm activity of irrigating solutions associated with cetrimide. Confocal laser scanning microscopy. Int Endod J. 2014;47(11):1058-63.

14- Kaushik N, Rehani U, Agarwal A, Kaushik M, Adlakha V. Antimicrobial efficacy of endodontic irrigants against Enterococcus faecalis and Escherichia coli: an in vitro study. Int J Clin Pediatr Dent. 2013;6(3):178-82.

15- Maria Ferrer-Luque C, Teresa Arias-Moliz M, Ruíz-Linares M, Elena Martínez García M, Baca P. Residual activity of cetrimide and chlorhexidine on Enterococcus faecalis-infected root canals. Int J Oral Sci. 2014;6(1):46-9.

16- Bukiet F, Couderc G, Camps J, Tassery H, Cuisinier F, About I, et al. Wetting properties and critical micellar concentration of benzalkonium chloride mixed in sodium hypochlorite. J Endod. 2012;38(11):1525-9. 17- Pozarowska D, Pozarowska P. Benzalkonium chloride (BAK) induces apoptosis or necrosis, but has no major influence on the cell cycle of Jurkat cells. Folia Histochem Cytobiol. 2011;49(2):225-30.

18- Guastalli AR, Clarkson RM, Rossi-Fedele G. The effect of surfactants on the stability of sodium hypochlorite preparations. J Endod. $2015 ; 41(8): 1344-8$ 
19- Portenier I, Waltimo T, Ørstavik D, Haapasalo M. Killing of Enterococcus faecalis by MTAD and chlorhexidine digluconate with or without cetrimide in the presence or absence of dentine powder or BSA. J Endod. 2006;32(2):138-41.

20- Stojicic S, Zivkovic S, Qian W, Zhang H, Haapasalo M. Tissue dissolution by sodium hypochlorite: effect of concentration, temperature, agitation, and surfactant. J Endod. 2010;36(9):1558-62. 21- Vogel AL. A textbook of quantitative inorganic analysis. London: Longmans; 1962.

22- Du Noüy PL. An interfacial tensiometer for universal use. J Gen Physiol. 1925;7(5):625-31

23- Camps J, Pommel L, Aubut V, Verhille B, Satoshi F, Lascola B, et al. Shelf life, dissolving action, and antibacterial activity of a neutralized $2.5 \%$ sodium hypochlorite solution. Oral Surg Oral Med Oral Pathol Oral Radiol Endod. 2009;108(2):e66-73.

24- Jungbluth $H$, Peters C, Peters O, Sener B, Zehnder M. Physicochemical and pulp tissue dissolution properties of some household bleach brands compared with a dental sodium hypochlorite solution. J Endod. 2012;38(3):372-5.

25- Niewierowski RS, Scalzilli LR, Morgental RD, Figueiredo JA, VierPelisser FV, Borba MG, et al. Bovine pulp tissue dissolution ability of irrigants associated or not to ultrasonic agitation. Braz Dent J. 2015;26(5):537-40.
26- Christensen CE, McNeal SF, Eleazer P. Effect of lowering the $\mathrm{pH}$ of sodium hypochlorite on dissolving tissue in vitro. J Endod. 2008;34(4):449-52.

27- Clarkson RM, Kidd B, Evans GE, Moule AJ. The effect of surfactant on the dissolution of porcine pulpal tissue by sodium hypochlorite solutions. J Endod. 2012;38(9):1257-60.

28- Frais $\mathrm{S}, \mathrm{Ng} \mathrm{YL}$, Gulabivala K. Some factors affecting the concentration of available chlorine in commercial sources of sodium hypochlorite. Int Endod J. 2001;34(3):206-15.

29- Gomes BP, Vianna ME, Sena NT, Zaia AA, Ferraz CC, Souza Filho FJ. In vitro evaluation of the antimicrobial activity of calcium hydroxide combined with chlorhexidine gel used as intracanal medicament. Oral Surg Oral Med Oral Pathol Oral Radiol Endod. 2006;102(4):544-50.

30- Gilbert P, Moore LE. Cationic antiseptics: diversity of action under a common epithet. J Appl Microbiol. 2005;99(4):703-15.

31- Luddin N, Ahmed HM. The antibacterial activity of sodium hypochlorite and chlorhexidine against Enterococcus faecalis: a review on agar diffusion and direct contact methods. J Conserv Dent. 2013;16(1):9-16.

32- De-Deus G, Berredo Pinho MA, Reis C, Fidel S, Souza E, Zehnder $M$. Sodium hypochlorite with reduced surface tension does not improve in situ pulp tissue dissolution. J Endod. 2013;39(8):1039-43.

33- Lewis, G, Randall M. International critical tables. New York: McGraw-Hill; 1930. 